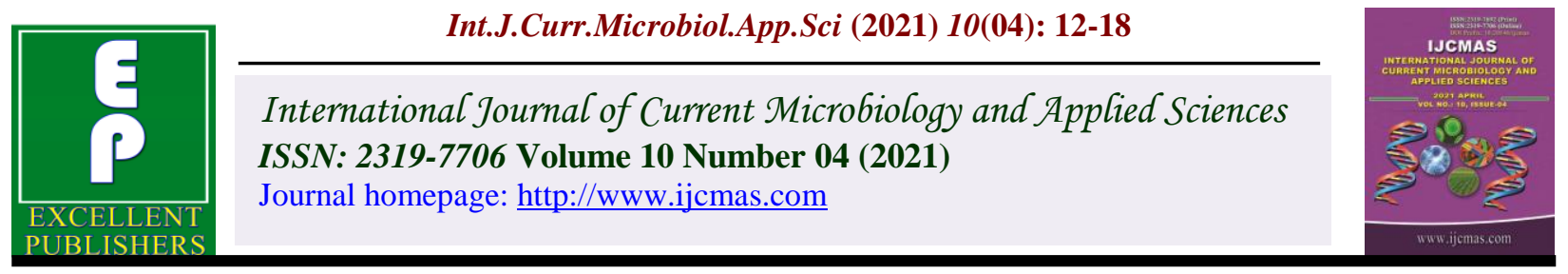

Review Article

https://doi.org/10.20546/ijcmas.2021.1004.002

\title{
Dry Flower Arrangement: A Review
}

\author{
Kshipra* \\ Department of Agriculture, Lovely Professional University, Phagwara-144411, Punjab, India \\ *Corresponding author
}

Keywords

Dry floral craft, floriculture, foliage, preservation and seeds etc

Article Info

Accepted:

12 March 2021

Available Online:

10 April 2021

\section{A B S T R A C T}

Dry floral craft is a fascinating art of preserving flowers and a form of value addition to the floriculture commodity. This form of line is underutilized and unexploited, can become an extension to crafting and farm businesses. Contrary to fresh flowers that ease off their attractiveness within hours, dry flower arrangement is found to be cheaper enduring from months to years with negligible care. This industry includes not only use of flower but every part of plant that can be dehydrated foliage, seeds, flower, stem etc. This article narrates the techniques for dehydrating and preserving plant materials for decoration and various purposes.

\section{Introduction}

Flowers have been remained innate part of human's life. From the birth to death, from welcoming to funeral, every occasion has involvement of flowers. Fresh flowers are most beautiful thing but is expensive, perishable and temporary and on the other side, Dried flowers are enduring, adds on aesthetics and is available all year round (Hiller, 1994). The dry floral crafts have been used for a long time for the purpose of beautification. Already there is an established market of dry flowers throughout the world, but In India it has not gotten that exposure for commercial entrepreneurial exploitation. There can be a variety of venture in this field and crafting the dried material through floral décor for homes and offices, bouquets, loose flower crafting like dry flower glass frames, potpourri, and so on. These dried arrangement keeps the line, texture and color of flower which can be used to get a equilibrate look for formal or informal occasions. And not confining only this, walls, greeting card, gift boxes, baskets, vases, candy jars, wedding cards, can be used considerably exhibit for dried floral arrangement. Crafting requires low feed in and high return build on work done with innovative and artistic skills yields aesthetic pleasure to eyes. And herein woman can join in with these crafts making small business which can be effortlessly managed by women from their home with family 
commitments. Also this industry till now is human dependent labor work, so it allows not only to women (or housewives or rural women) but also to men especially physically differently abled people.

\section{Global overviews}

The idea of these preservation plant materials is not new, but is an ancient art form. Egyptian used dried herbs for fragrance in cases of mummified bodies. Around middle age, monks used in as decorative logos and for also making dyes for their hand-printed books. Later American also used it as decorative purpose in their homes to brighten up especially during winters. In Japan, there is an art form of using flower pressing technique to make an entire picture called as Oshibana art.

\section{Principles and Practices}

The basic principle of dried floral art is to dehydrate flower, remove the moisture sideways maintaining the original shape and texture of the material to an extent possible. And quite a lot of flowers responded fine for drying such as zinnia, allium, sweet William, carnation, stock, marigold, rose, lilies, etc. (Rogers, 1988). There are various ways of drying discussed below and on the basis of plant character, suitable drying method to be selected (Mishra et al., 2003).To get positive result on drying, the selection of crop and variety is necessary. Few flowers lose their attractive feature and ornamental values after the process of drying. Some flowers like sweet pea when used for press drying fades away the original color and left out with brown color which has no further essence for decoration (Louis and Gibson, 1982). The quality delivered after drying varies from flower crop of different cultivars. Example - Helichrysum, even though the petals are solid but still after drying its petal fall downwards and even some florets shed away and shape gets distorted. This characteristic is majorly seen in yellow cultivars then in any other (Sangama, 2004). While harvesting the flower the things that needs to be taken care. The flower should be closely packed, potent stem or else wiring can be done in weak stem case, and a fairly less moisture content. While selecting flowers inferior shapes (without texture and lines) will lead to poor state dried flower. Also, flowers harvested at fully bloomed stage takes lesser time to dry than those of at half opened flower or tight buds (Sangama, 2004). Contrary to this, Safeena et al., (2006a) comes up with statement that half bloomed stage requires minimum time to dry. So may be drying depend on various other factors like sensitivity to ethylene and senescence too. Moisture is the ruling factor which influences the shape of flower after drying. The minimum the moisture content is the higher rigidity which results in the constant cell contraction.

Also, the longevity of flower is inversely proportional to the moisture content. $8-12 \%$ is ideal content ensuring best quality dried flower. Excess drying can lead to vulnerability and shredding of flower (Singh, 2004). After collection, cleaning should be done i.e. peeling and stripping of stem. These are pre drying flower procedures.

\section{Methods of drying}

Water drying, freeze drying, and glycerin drying has principle of preserving by removing moisture. In glycerin drying the water content in flower is replaced by combination of glycerin and water keeping the quality superior. The principle behind freeze drying is sublimation that during dehydration process in absence of liquid moisture this conveys that there is unwanted reactions will not take place; therefore in dried flower fragrance and color are maintained (Dubois and Joyce, 2005). Beside it, there are many different types of drying process which are applicable on variety of flowers which is described below, 


\section{Air drying}

This technique is effortless without any equipment to get a crisp look for bouquets. This can be named as 'hang and dry' method. The flower along with its stem needs to be tied in a bunch and hanged bottom up. The environment provided should be dark, warm and good aeration with low humidity. It is one-off earliest and longest method. It requires at least 3 weeks getting totally dry. Moreover, during the hanging process by themselves they add beauty to décor as all the bunches hanged upside down in a row. The flowers chosen for air drying should be slightly at immature stage.

The reason behind hanging upside down is to protect the stem from not being distorted, if dried on standing stem would bend. And to add more to retain its shape and color chemicals can be added. More the foliage and flesh in flower, more the time required for drying (White et al., 2002). Pink color fades away in this drying but other colors like blue and yellow still able to preserve. In addition there is natural drying process, which is for pines. These kept on drying while attached to plant it. With using this method many products can be made like

\section{Hot air oven drying}

It is finest techniques as of consume very less time. It is the quickest method, depending onto the flower size usually takes 20-25 mins for drying. The principle behind technique is discharging of moisture by unsettling water molecule present in material at the hand of microwave. Temperature is the main component, so start off with a low setting and gradually can be increased. Higher the temperature, faster the degradation of pigments leading to loss of color (Singh et al., 2004). Also it has been observed that fully matured/opened flower is not fit for oven drying (Prasad et al., 1997). Microwave dried flower should be sprayed with hair spray to block the adsorption of moisture from air. Some reported that oven drying makes flower look fresh and Bright-colored as compared to other methods (white et al., 2002). Studies show the effect of hot oven drying on chrysanthemum in embedding agent sand and reported that there was no morphological change in flower like color, structure, but the chlorophyll content in floral parts was reduced in significant amount (Pandya et al., 2001).

\section{Pressed drying}

It is plain practice of drying by applying pressure on foliage or flower leaving the moisture off and keeping together the color and structure. There a ways to apply pressure that is keeping material in blotting paper under books, or even in a newspaper; or with equipment called plant press. Plant press is designed to flattening the samples. This technique was first used in 1820 but later used for preparing herbarium (Lawerence, 1969).

There's a disadvantage to this technique because of moisture and cellulose of paper provides substrate to microbes for sporulation and growth of microorganism. By this method color can be preserved but not shape (Datta, 1997). By this method glass frames can be prepared.

\section{Embedding drying}

This technique uses a desiccant which is anhydrous i.e. drying agent has high affinity for water. Flower is embedded in some desiccant like sand or silica gel in a plastic container. As in air drying due to the loss of moisture, there is shrinkage and morphology of ornamental flower gets changed (Desh Raj, 2006). 
Fig.1 Bouquet making
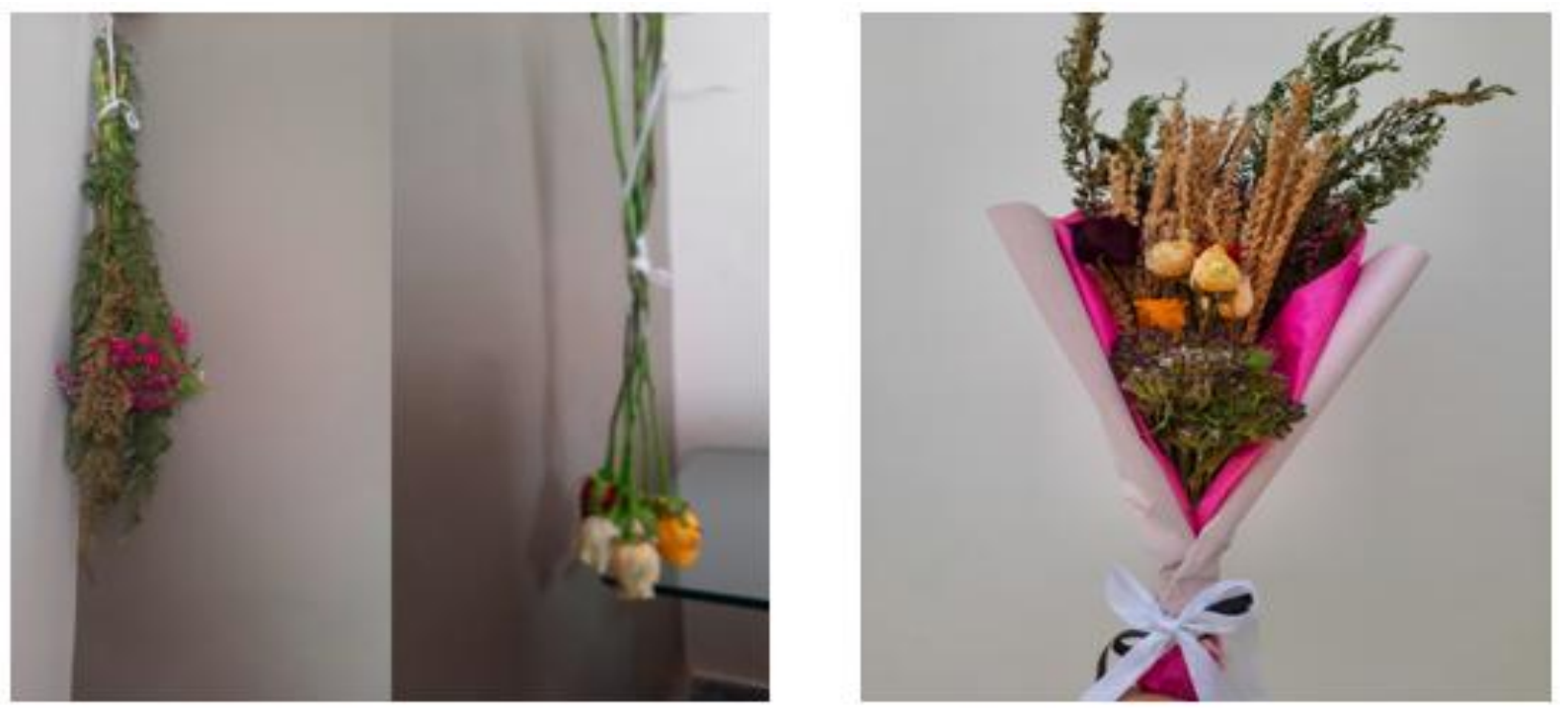

Fig.2 Potpourri - By simply drying flower petals in air. After drying lavender oil can be added for fragrance purpose and can be packed in different ways
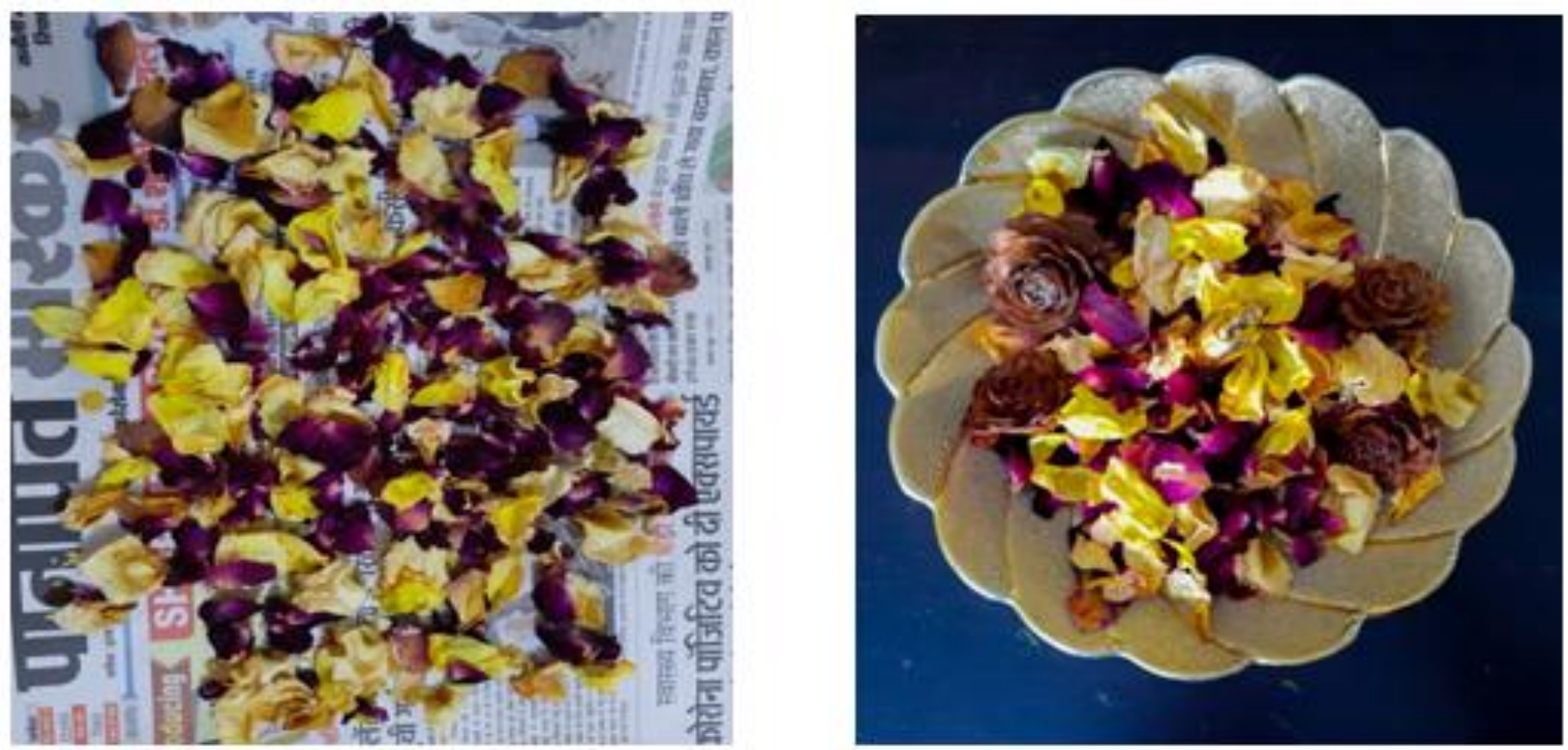
Fig.3
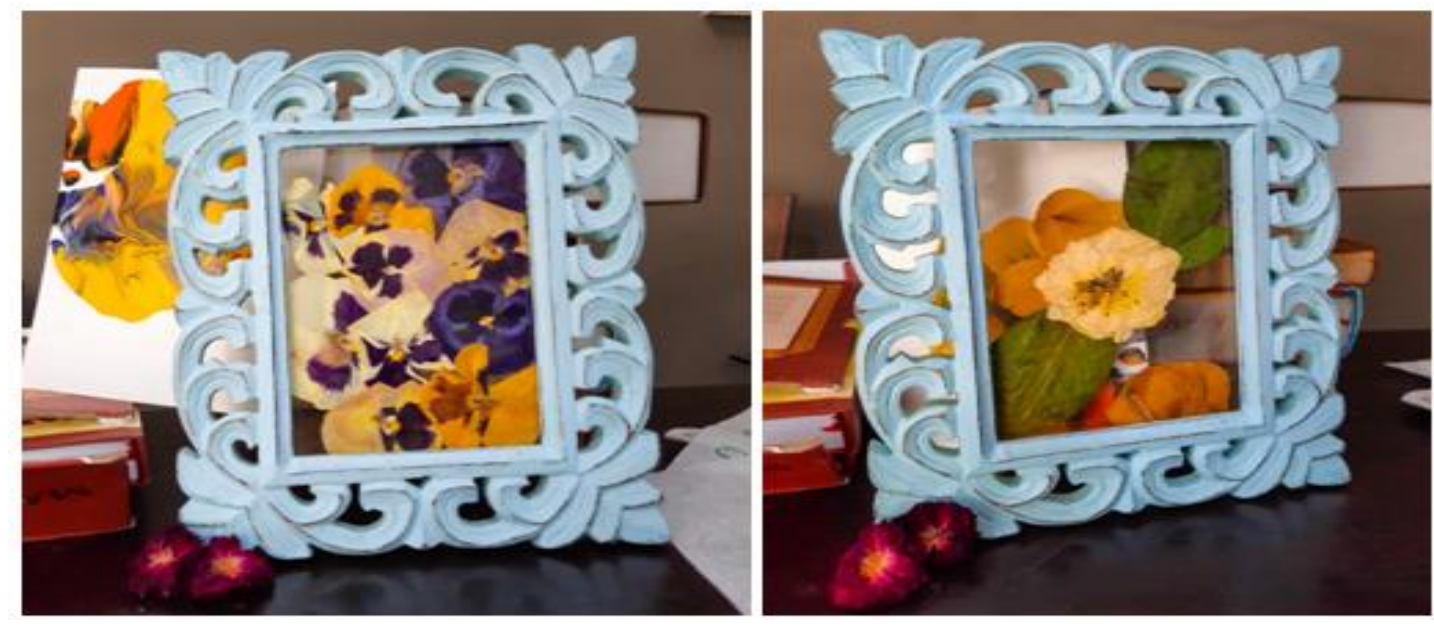

Fig.4
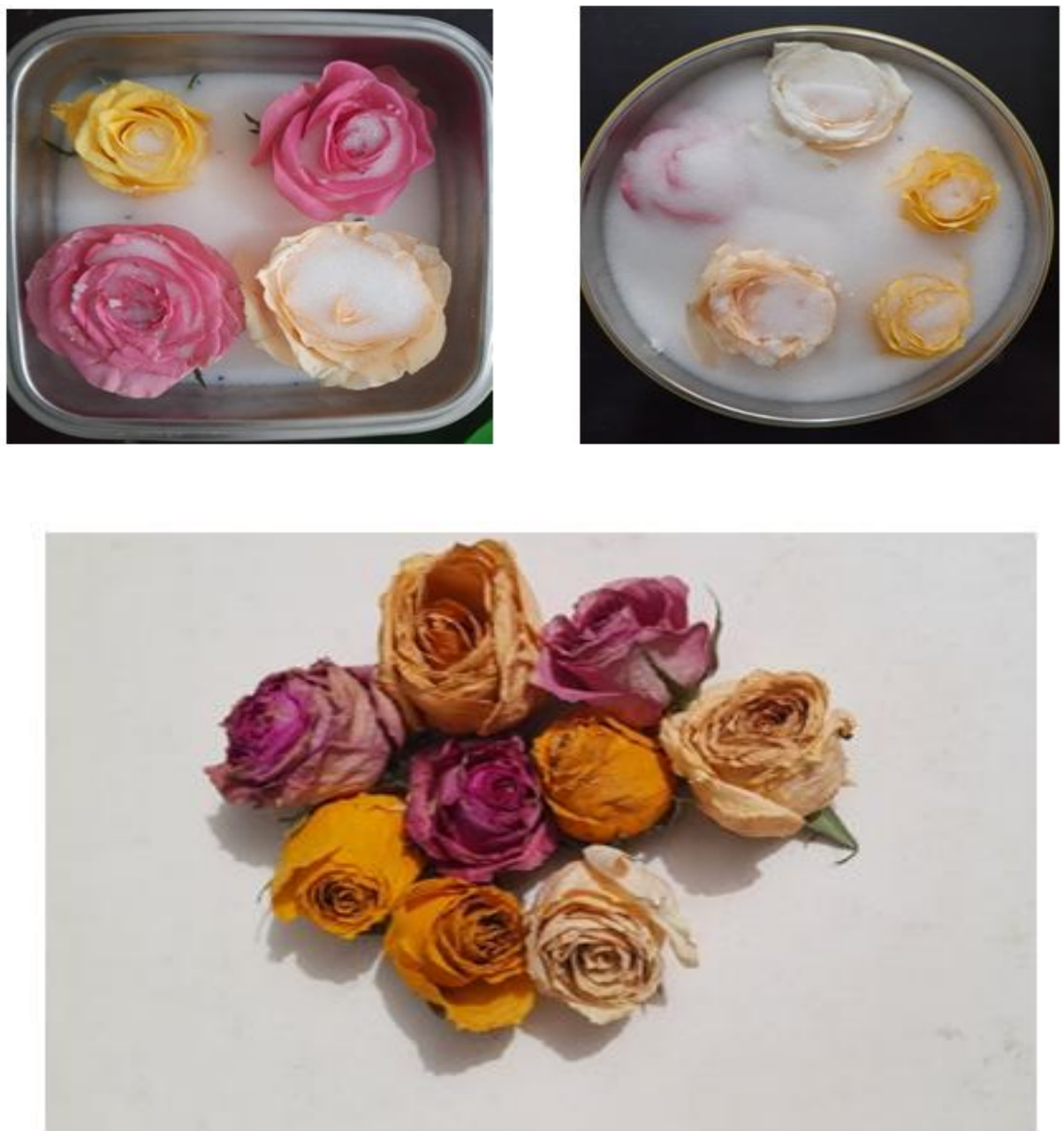
The plus point for this method is the shape is undisturbed retaining natural form. This is ideal for delicate flowers like dahlia, carnation and roses (Prasad et al., 1997). Other agents like perlite, borax, sawdust can also be used. It is mentioned that silica gel is not a gel but is xerogel of silicic acid which is granular/solid formed from a gel by drying (Orduno and Baltazar, 1995). Silica gel hold a property called physical adsorption and capillary condensation which attracts and holds moisture in microscopic pores. By these phenomena this gel is fastest and easiest acting desiccant (Neave, 1996). Though silica gel is expensive but is recyclable, when the color of crystals is changed, then they can be warmed up in oven to reuse it. Silica gel embedding holds the color of flower (Sandhu, 2002). Drying can be made much faster by using mixture of 2 desiccants like silica gel and borax. Also, for flowers like chrysanthemum and dahlia another mixture which showed good and quick results was borax and corn meal in ration of 1:1 (Sell, 1993). Another best example can be sand and borax because of texture and brightness retention (Sujatha et al., 2001). Drying medium will influence the morphology of dried flower. Like with sand the texture observed was smooth but with silica and borax little roughness and harsh roughness respectively was recorded (Singh et al., 2002).

\section{Handling and Post drying processes}

Dry flowers are less elastic and susceptible to damage while handling. So, there is a requirement of different packaging technology for making dried flower more enduring. Also a total handling or post-drying practices should be explored and standardized. Moreover, before exploiting this field for commercial purpose, there is urging for apt treatments on dried flower to secure hardening because dry flowers are hygroscopic (i.e. moisture absorbing) and reabsorb moisture quickly.
The art in floriculture can plate up to lay out the uniqueness flower community. Out there is a unexplored abundant material and market for this produce. There is just not enough recognition to different forms existing that can establish eye-catching aesthetic products and its audience. This business stands in need of popularizing the field of line to make potential use of these techniques.

\section{References}

Alka Singh (2017) Floral craft for improved livelihood and women empowerment. International Journal of Information Research and Review 4(05), 4160-4163.

Arvinder Singh, Nomita Laishram (2010) Drying of flowers and other ornamental plant parts in India. Floriculture and Ornamental Biotechnology 4 (1), 72-78, Global Science Books.

Datta S K (1997) Dehydration of flowers and foliage and floral craft. NBRI Bulletin No. 3, EBIS, NBRI, Lucknow, 20 pp.

Desh Raj (2006) Drying of attractive plant parts and flowers. In: Advances in Ornamental Horticulture (Vol V), Pointer Publishers, Jaipur, pp 189-198.

Dubois P, Joyce D (1989) Drying cut flowers and foliage. Farm note No. 10/89, Western Australian Department of Agriculture, 3 pp.

Growing, Drying and Displaying, Dorling Kindersley Ltd., London, 230 pp

Hiller M (1994) Guide to Arranging Dried Flowers. Step by Step Handbook of

Lawrence HMG (1969) Taxonomy of Vascular Plants, Oxford and IBH Publishing Co. Inc., Calcutta, 777 pp.

Louis J, Gibson L (1982) The Complete Guide to Drying and Preserving Flowers, Webb and Bower Ltd., England, 280 pp.

Mishra R L, Kumar N, Ranjan JK (2003) Exploring export potential of dried flowers, floral crafts and value added products. Indian Horticulture 48 (2), 4748.

Neave L (1996) Preserving fresh flowers. Horticulture home and pest news. Available online: 
http://www.ipm.iastate.edu/hortnews/1996 /8-9-1996/preservefresh.html

Orduno C A, Baltazar B (1995) Effect of different mixtures of sand and borax on the drying of three flower species. Revista Chapingo Serie Horticulturae 1(3), 93-97.

Pandya H P, Saxena O P, Nell T A, Clark D G (2001) Preservation of Chrysanthemum sp. by drying. Acta Horticulturae 543, 367-369.

Prasad JJK, Pal PK, Voleti SR (1997) Drying of flowers: an upcoming industry. Floriculture Today 4 (6), 20-23.

R. J. Makwana et al., (2018) Role of women in floral decorations, floral crafts and floral jewellery : International Journal of Emerging Technologies and Innovative Research, Vol.5, Issue 11, pp390-394.

Rogers BR (1988) Drying flowers. In: The Encyclopedia of Everlastings, Michael Friend man Publishing Group, New York, 199 pp.

Safeena S A, Patil V S, Naik B H (2006a) Standardization of stage of harvest for better quality of dry flowers of rose. Journal of Ornamental Horticulture 9(3), 224-226.

Saima Mir, B. M Shinde, M. G. Chaskar, M. M. Jana (2019) Dry flower and floral craft: For better subsistence and women empowerment. International Journal of Research and Analytical Reviews (IJRAR), 6(1), 209-213.

Sandhu A (2002) Studies on the dehydration of winter annuals. MSc thesis, Punjab Agricultural University, Ludhiana, Punjab, $86 \mathrm{pp}$.

Sangama (2004) Dehydration and product diversification of Helichrysum flower. Journal of Ornamental Horticulture 7 (3), 376-380.

Sell R (1993) Dried and fresh cut flowers. NDSU Extension Service, North Dakota State
University of Agriculture and Applied Science, USA, $62 \mathrm{pp}$.

Shailza*, Shalini Jhanji and H. S. Grewal (2018) Emerging Prospective of Floriculture Industry: Drying of Ornamental Plants and their Parts. International Journal of Current Microbiology and Applied Sciences, 7(07), 1619-1633.

Sharvani, Ch.S.R. and Sree, G. D. 2018. Dry flowers- A boon to floriculture industry. Journal of Postharvest Technology, 6(3): 97-108.

Singh A (2004) Study of dehydration of Zinnia. Indian Journal of Plant Physiology 9 (4), 383-387.

Singh A, Dhaduk B K, Shah R R (2002) Effect of different drying conditions and temperatures on chloroplast and vacuolar pigment content in Zinnia flowers. Journal of Ornamental Horticulture 5 (2), 66.

Singh A, Dhaduk B K, Shah R R (2004) Effect of different temperature and embedding media on flower dehydration of zinnia (Zinnia linearis Benth.). Indian Journal of Horticulture 61 (3), 249-252.

Singh D.B. (2003): Exploring export potential of dried wild flowers and their value added products. Indian Horticulture, 48:38-40.

Singh Deepti (2018) Comparative Drying Method Study in Different Flowers with Respect to Quality Dry Flower Products Preparation. International Journal of Agriculture Sciences, ISSN: 0975-3710 \& E-ISSN: 0975-9107, Volume 10, Issue 3, pp- 50925094.

Sujatha A N, Damodaran T, Shiva KN (2001) Dry flower industry in Andamans. Kissan World 28, 28.

White P, Tijia B, Sheehan M R (2002) Drying and preserving plant materials. University of Florida Co-operative Extension Service, $53 \mathrm{pp}$.

\section{How to cite this article:}

Kshipra. 2021. Dry Flower Arrangement: A Review. Int.J.Curr.Microbiol.App.Sci. 10(04): 1218. doi: https://doi.org/10.20546/ijcmas.2021.1004.002 